\title{
Improvement of Antibacterial Activities of Bacteriocidal Yeasts Using the GPD Promoter
}

\author{
Min-Kyung Jang, Ki Hwan Yu, Nam-Young Kim, Ok-Hee Lee, Jae-Kyun Shin, Hye Ji Jang, \\ Seungwoo Lee, Dong-Geun Lee and Sang-Hyeon Lee*
}

Department of Pharmaceutical Engineering, Silla University, San 1-1, Gwaebop-dong, Sasang-gu, Busan 617-736, Korea

Received April 7, 2010 / Accepted April 13, 2010

\begin{abstract}
We have previously reported recombinant productions of bacteriocins using yeast expression plasmid pAUR123, which contains the alcohol dehydrogenase (ADH) promoter, in Saccharomyces cerevisiae cells and their antibacterial activities. In order to improve the antibacterial activities of bacteriocidal yeast cells, a strong glyceraldehyde phosphate dehydrogenase (GPD) promoter gene of $S$. cerevisiae was amplified and inserted upstream into bacteriocin genes such as the OR-7, Subpeptin JM4-A or JM4-B gene in the corresponding recombinant yeast plasmid. Yeast cells transformed by the recombinant plasmid containing the GPD promoter represented higher antibacterial activities against both Gram positive B. subtilis and Gram negative E. coli cells compared to those transformed by the corresponding recombinant plasmid containing the $\mathrm{ADH}$ promoter. Thus, yeast cells harboring the recombinant plasmid containing the GPD promoter constructed in this study could be applied in the food preservative or animal feed industries.
\end{abstract}

Key words : Bacteriocidal yeast, bacteriocin, GPD promoter, OR-7, Subpeptin JM4-A, Subpeptin JM4-B

\section{서 론}

현재 미생물에 의한 식품의 부패와 변질을 막고 저장성을 향상시키기 위한 방법으로 인공 첨가제 및 인공 항생물질을 사용하고 있다. 하지만 인공 첨가제들은 인체에 대한 잔류성 과 독성으로 인해 여러 가지 부작용을 동반하기 때문에 사회 문제로 대두되고 있는 실정이다[1]. 인공첨가제 중 의약품인 항생물질은 공업적, 화학적 방법으로 생산되고 있으며, 화학 적 인공 항생물질이 포함된 사료를 먹인 가축을 인간이 섭취 하면 부작용으로 인한 여러 가지 질병이 나타날 수 있다. 또한 항생제의 남용으로 인한 내성균의 발생과 전파라는 문제점으 로 선진국에서는 항생제 사용에 있어 많은 제약을 두는 실정 이다[4].

박테리오신(bacteriocin)은 여러 종의 미생물들이 생산하는 항균성 펩타이드로서, 각종 식중독균과 유해세균에 대한 뛰어 난 항균효과를 지니고 있어 식품산업에서 잠재력을 지닌 천연 신소재로 부각되고 있다[1,10,14]. 박테리오신에 관한 연구는 20여 년 전부터 가속화되어 유럽이나 미국에서는 이미 산업화 적용 단계에 있으며, 우량 균주 확보 및 특허 출원 등의 다양한 연구가 진행되고 있다[5]. 이러한 박테리오신은 고온에서도 활 성을 유지하고 광범위한 $\mathrm{pH}$ 에서도 안정하며, 무독, 무색, 무취 이며 잔류성이 없다는 장점으로 식품 등에서 천연 방부제로 사용이 가능하다[1,18]. 인공 항생제는 사람에게 투여 시 부작

\footnotetext{
*Corresponding author

Tel : +82-51-999-5624, Fax : +82-51-999-5636

E-mail : slee@silla.ac.kr
}

용이 있다는 단점이 있으나 박테리오신은 단백질 가수분해 효소에 의해 분해되어 잔류성이 없어 안전하기 때문에 식품 등의 생물학적 보존제(biopreservative) 및 발효식품의 생물제 어제(bioregulator)로 이용되고 있다[6,7].

박테리오신은 유전자 분석 및 조작을 통하여 생산량을 최대 화하는 것이 용이하고 분자적 변이를 통한 우수한 박테리오신 을 합성할 수 있다는 장점이 있지만, 일반적으로 유전자의 발 현에 이용되고 있는 대장균을 포함하는 세균들의 경우는 도입 된 박테리오신 유전자 산물의 항균활성 때문에 생산균주로서 의 활용이 불가능하다는 단점이 있다[11]. 따라서 항균활성 펩 타이드의 생산을 위해서는 일반적으로 박테리오신에 대한 생 육저해활성을 나타내지 않는 진핵생물에 속하는 효모세포인 Saccharomyces cerevisiae 등을 숙주로 사용함으로써 이러한 문 제점을 해결할 수 있고, 효모세포로부터 추출한 yeast extract 는 현재 세균배양 배지에 첨가하는 영양성분으로서 질소화합 물, 당, 무기영양소 및 유기영양소 등을 함유하고 있기 때문에 배양된 효모 균체만으로도 가축사료의 좋은 영양성분으로 활 용될 수 있다[11,12].

최근, 효모를 이용한 외래 단백질의 상업적 생산이 크게 강 조되면서 유전자 고발현을 위한 숙주세포의 변이주, 고발현 벡터 및 신기능성 효모의 개발 등에 관한 연구가 활발히 진행 되고 있다[15]. 재조합 효모에서 외래 유전자의 고발현을 위한 주요 고려인자로 plasmid copy number, 전사효율, repressor 및 inducer의 농도, 프로모터의 강도 등이 알려져 있다 $[2,3,8,13,15]$. 일반적으로 plasmid copy number는 유전자 고 발현을 유도시키지만, copy number가 너무 높거나 과발현은 
숙주세포에 대사적 불균형을 초래하게 되어 균체의 증식속도 나 증식수율을 감소시키거나 도입된 plasmid의 불안정성을 유발하여 재조합 단백질의 생산성을 감소시키는 원인이 되기 도 한다[2,8,15]. 이러한 문제점을 해결하기 위한 방법으로 강 력한 프로모터를 사용하여 균체증식과 유전자 발현을 분리하 여 조절함으로써 재조합 단백질의 생산성을 향상시킬 수 있다 $[8,13,15]$. 효모세포인 S. cerevisiae에 사용되는 대표적인 프로 모터의 종류로는 유도성 프로모터인 GALI (galactokinase I) 프로모터, 상시성 프로모터인 GPD (glyceraldehyde-3-phosphate dehydrogenase) 프로모터와 ADHI (alcohol dehydrogenase I) 프로모터 등이 있다[15].

본 연구에서는 박테리오신 유전자가 도입된 효모의 항균활 성을 개선하기위해 선행연구에서 얻어진 항균활성 플라스미 드 DNA (pAUR-OR-7, pAUR-SubpA 및 pAUR-SubpB) $[11,12]$ 에 GPD 프로모터 유전자 단편을 삽입하여 기존에 개발 된 항균활성 효모의 활성 증진을 시도하였으며, 그람양성 대 표세균인 Bacillus subtilis 및 그람음성 장내세균인 Escherichia coli에 대한 기존의 재조합 효모와의 항균활성을 비교하였다.

\section{재료 및 방법}

\section{시약 및 배지}

제한효소, DNA ligation kit, Pyrobest DNA polymerase, Taq DNA polymerase는 Takara Korea (Seoul, Korea)에서 구 입하였다.

효모의 발현 플라스미드 DNA는 alcohol dehydrogenase $(\mathrm{ADH})$ 프로모터에 의해 발현이 유도되는 pAUR123 (Takara Korea, Seoul, Korea)을 사용하였다.

유전자 클로닝을 위한 숙주로는 대장균(E. coli DH5a) 세포 를 사용하였다. 대장균은 LB 배지 $(1 \%$ bacto tryptone, $0.5 \%$ yeast extract, $0.5 \% \mathrm{NaCl}$ )를 이용하여 $37^{\circ} \mathrm{C}$ 에서 배양하였다. 대장균 형질전환체의 선별을 위해서는 LB 배지에 ampicillin 을 최종농도가 $100 \mu \mathrm{g} / \mathrm{ml}$ 가 되게 첨가하여 사용하였다. 고체 배지는 $\mathrm{LB}$ 배지에 한천(agar)을 $1.5 \%$ 가 되도록 첨가하여 제작 하였다.

효모의 발현 플라스미드 DNA의 형질전환을 위한 숙주로 는 효모(S. cerevisiae KCTC 7913) 세포를 사용하였다. 효모는 YPD 배지(1\% yeast extract, 2\% polypeptone, 2\% D-glucose) 를 이용하여 배양하였다. YPD 고체배지는 YPD 배지에 한천 을 $1.5 \%$ 가 되도록 첨가하여 제작하였다.

\section{GPD 프로모터 유전자의 획득 및 염기서열 분석}

GPD 프로모터 유전자의 획득을 위하여 S. cerevisiae의 염색 체 DNA로부터 forward primer GPDp4-F(5'-CCGGTACC CCAGAGCTCCGATCTCGAGC-3')와 reverse primer GPDp2R(5'-GGTACCTCGAAACTAAGTTCTTGG-3')을 사용하여 GPD
프로모터 유전자 부위를 PCR법으로 증폭하였다. 각각의 primer에는 클로닝을 위하여 $5^{\prime}$ 말단에 제한효소 $\mathrm{KpnI}$ 의 인식부 위를 도입하였다. PCR 반응 조건으로 초기해리는 $94^{\circ} \mathrm{C}$ 에서 5 분간 시행하였고, 해리 $\left(94^{\circ} \mathrm{C}, 1\right.$ 분), 혼성화 $\left(55^{\circ} \mathrm{C}, 1\right.$ 분) 및 중합 $\left(72^{\circ} \mathrm{C}, 1\right.$ 분 $)$ 의 세 과정을 30 회 반복하고, 추가적인 중합 $\left(72^{\circ} \mathrm{C}\right.$, 10 분)을 수행하였다. PCR법으로 증폭된 DNA 단편은 서브클 로닝을 위해 pBT-1.1 vector (Bio-solution, Gyeonggi-do, Korea)에 연결하여 $\mathrm{pBT}-\mathrm{GPDp}$ 를 제작하였다. 제작된 $\mathrm{pBT}$ $\mathrm{GPDp}$ 플라스미드 DNA를 이용하여 대장균 세포(E. coli DH5 a)를 형질전환시켰으며, 이로부터 플라스미드 DNA를 추출하 였다. GPD 프로모터 유전자를 확인하기 위하여 추출된 플라 스미드 $\mathrm{DNA}$ 를 제한효소 $\mathrm{KpnI}$ 으로 절단하고 $0.8 \%$ agarose gel에서 전기영동을 수행하여 DNA 단편을 확인하였다. 한편, 염기서열 분석을 위해 추출된 플라스미드 DNA를 (주) 바이오 니아(Seoul, Korea)에 의뢰하여 염기서열을 밝히고, 밝혀진 염 기서열을 DS Gene 1.5 program (Accelrys Inc., Seoul, Korea) 을 이용하여 제한효소 절단부위 등을 확인하였다.

\section{항균활성 효모의 활성 개선을 위한 발현 플라스미드 DNA 의 구축 및 형질전환 효모의 제작}

항균활성 효모의 활성을 개선하기 위해 pBT-GPDp 플라스 미드 DNA를 제한효소 KpnI으로 절단한 후 $748 \mathrm{bp}$ 의 GPD 프로모터 유전자 단편을 추출하고 pAUR123 (Takara Korea, Seoul, Korea)과 선행연구에서 개발한 박테리오신 생산 플라스 미드 DNA인 pAUR-SubpA, pAUR-SubpB [11] 및 pAUR-OR-7 [12]의 KpnI 부위에 삽입하였고, 제한효소를 이용하여 삽입된 $\mathrm{GPD}$ 프로모터 유전자 단편 및 그 방향성을 확인하였다. 구축 된 발현 플라스미드로 electroporation (Cell-Porator, Life technologies, MD, USA)법에 의해 효모세포(S. cerevisiae KCTC 7913)를 형질전환시켰다. 형질전환된 효모세포의 선별 은 YPD 배지에 aureobacidin A (Takara Korea, Seoul Korea) 를 최종농도가 $0.2 \mu \mathrm{g} / \mathrm{ml}$ 이 되게 첨가한 후 $30^{\circ} \mathrm{C}$ 에서 3 일간 배양하여 행하였다.

\section{형질전환 효모로부터 플라스미드 DNA의 분리 및 확인}

재조합 플라스미드 DNA가 형질전환된 효모를 aureobacidin $\mathrm{A}$ (최종농도 $0.2 \mu \mathrm{g} / \mathrm{ml}$ )가 첨가된 $\mathrm{YPD}$ 배지 $4 \mathrm{ml}$ 에 접종하여 $30^{\circ} \mathrm{C}$ 에서 하룻밤 동안 배양한 후, 원심분리 $(14,000 \times$ $g, 5$ 분)하여 균체를 회수하였다. 여기에 yeast lysis buffer $(2 \%$ triton X-100, 1\% SDS, $10 \mathrm{mM}$ tris- $\mathrm{HCl}$ (pH 8.0) buffer, $1 \mathrm{mM}$ EDTA) $200 \mu 1$ 를 넣어 균체를 현탁시킨 후, acid-washed glass beads (425-600 $\mu \mathrm{m}$, Sigma, MO, USA) $0.3 \mathrm{~g}$ 과 phenol/ $\mathrm{CHCl}_{3}$ 용액 $200 \mu 1$ 를 넣고 2 분간 vortex를 행하였다. $4^{\circ} \mathrm{C}$ 에서 원심분 리(14,000× $\mathrm{g}, 10$ 분)를 행하여 상층액을 새로운 tube에 옮기고, 여기에 glycogen $1 \mu \mathrm{l}, 5 \mathrm{M} \mathrm{LiCl}$ 용액 $20 \mu \mathrm{l}$, cold 에탄올 500 $\mu \mathrm{l}$ 를 첨가한 후, 원심분리 $(14,000 \times g, 10$ 분 $)$ 를 행하여 플라스미 
드 $\mathrm{DNA}$ 를 침전시켰다. 침전된 $\mathrm{DNA}$ 는 $70 \%$ 에탄올로 세정한 후 건조시키고, 멸균 초순수 $\left(\mathrm{ddH}_{2} \mathrm{O}\right) 20 \mu \mathrm{l}$ 에 녹였다. 형질전환 효모로부터 회수된 플라스미드 $\mathrm{DNA}$ 를 이용하여 대장균 세포 (E. coli DH5a)를 형질전환시켰으며, 이로부터 플라스미드 $\mathrm{DNA}$ 를 추출하였다. GPD 프로모터 유전자를 확인하기 위하 여 추출된 플라스미드 $\mathrm{DNA}$ 를 제한효소 $\mathrm{KpnI}$ 으로 절단하고 $0.8 \%$ agarose gel에서 전기영동을 수행하여 DNA 단편을 확인 하였다.

\section{항균활성 측정}

그람양성 대표세균인 고초균(B. subtilis ATCC 6633)과 그람 음성 장내세균인 대장균(E. coli KCTC 2223)을 LB 배지를 이용 하여 $30^{\circ} \mathrm{C}$ 에서 하룻밤 동안 진탕배양 $(250 \mathrm{rpm})$ 하고, 사용하기 전에 이를 100 배로 희석하였다. 균 희석액을 YPD 고체배지에 도말하였고, 여기에 프로모터를 가진 박테리오신 생산 플라스 미드 DNA가 도입된 형질전환 효모와 대조군으로 효모의 발 현벡터 pAUR123에 GPD 프로모터만 삽입한 플라스미드 $\mathrm{DNA}$ 가 도입된 형질전환 효모, 기존에 개발한 $\mathrm{ADH}$ 프로모터 만을 가진 박테리오신 생산 플라스미드 DNA가 도입된 형질 전환 효모 배양액을 각각 $20 \mu \mathrm{l}$ 씩 일정부위에 접종하고 $30^{\circ} \mathrm{C}$ 에서 하룻밤 동안 배양한 후 항균작용에 의해 형성된 생육 억제환(clear zone)을 비교 · 관찰하였다.

\section{결과 및 고찰}

\section{GPD 프로모터 유전자의 클로닝 및 확인}

S. cerevisiae의 염색체 DNA로부터 PCR법에 의해 $748 \mathrm{bp}$ 의
GPD 프로모터 유전자의 단편을 증폭하였고, 이를 pBT-1.1 vector에 연결하여 $\mathrm{pBT}-\mathrm{GPDp}$ 를 제작하였다. 삽입된 유전자 단편의 염기서열을 분석한 결과, $5^{\prime}$ 및 $3^{\prime}$ 말단에서 제한효소 KpnI 부위를 확인할 수 있었으며, S. cerevisiae의 GPD 프로모 터 유전자임을 확인할 수 있었다(Fig. 1).

GPD 프로모터 유전자의 단편이 삽입된 박테리오신 생산 재조합 플라스미드 DNA의 구축 및 항균활성 효모의 제작

pBT-GPDp를 제한효소 KpnI으로 절단하여 $748 \mathrm{bp}$ 의 GPD 프로모터 유전자의 단편을 획득하였고, 이를 pAUR123과 선 행연구에서 개발한 박테리오신 발현 플라스미드 DNA들의 제 한효소 KpnI 부위에 삽입하여 이를 각각 pAURG (Fig. 2A), pAURG-SubpA (Fig. 2B), pAURG-SubpB (Fig. 2B) 및 pAURG-OR-7 (Fig. 2C)이라 명명하였다. 구축된 박테리오신 생산 재조합 플라스미드 DNA로 효모 세포(S. cerevisiae)를 형 질전환시켜 항균활성 효모를 제작하였으며, 이로부터 분리된 플라스미드 $\mathrm{DNA}$ 를 제한효소 $\mathrm{KpnI}$ 으로 절단하여 확인한 결 과, $748 \mathrm{bp}$ 의 GPD 프로모터 유전자의 단편을 확인할 수 있었 다(Fig. 3).

\section{형질전환 효모의 항균활성 비교}

재조합 플라스미드 DNA인 pAURG, pAURG-SubpA, pAURG-SubpB 및 pAURG-OR-7이 도입된 형질전환 효모들 을 이용한 항균활성을 선행연구에서 보고한 pAUR123, pAUR-SubpA, pAUR-SubpB 및 pAUR-OR-7이 도입된 형질 전환 효모들과의 항균활성을 비교한 결과, $\mathrm{ADH}$ 프로모터에 의해 박테리오신 유전자를 발현시키는 기존의 형질전환 효모

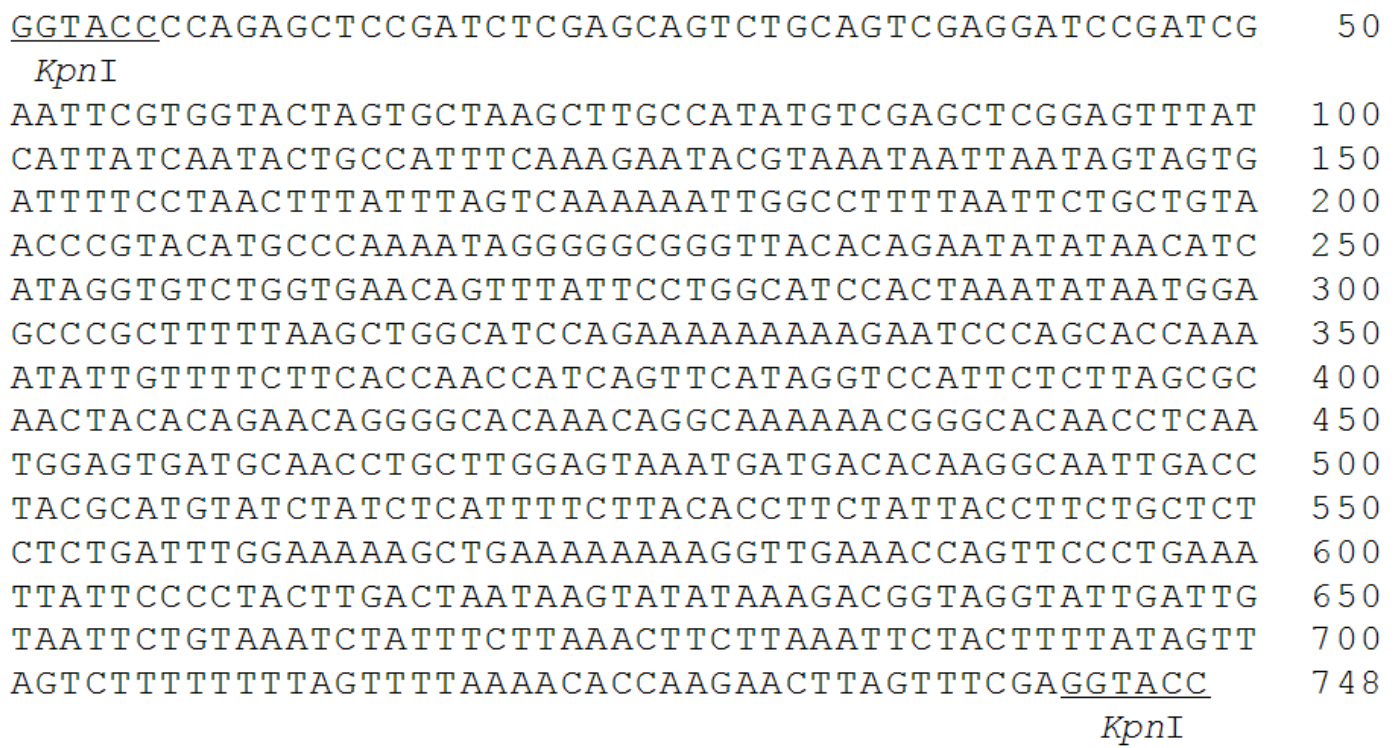

Fig. 1. Nucleotide sequence of the cloned GPD promoter gene. Restriction sites of KpnI were introduced both at $5^{\prime}$ - and $3^{\prime}$-ends of the gene. 
A

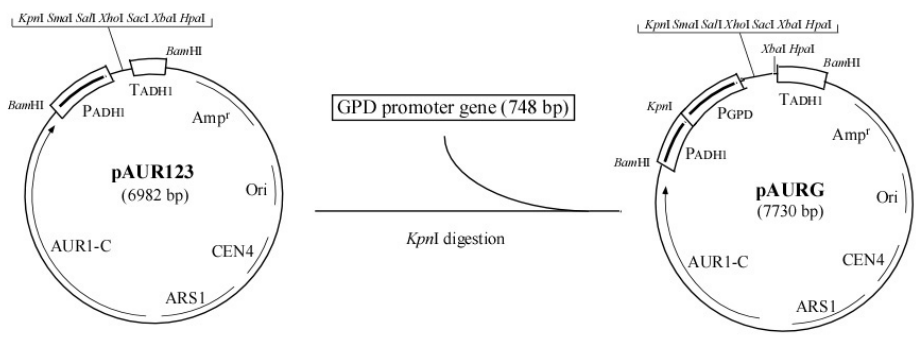

B

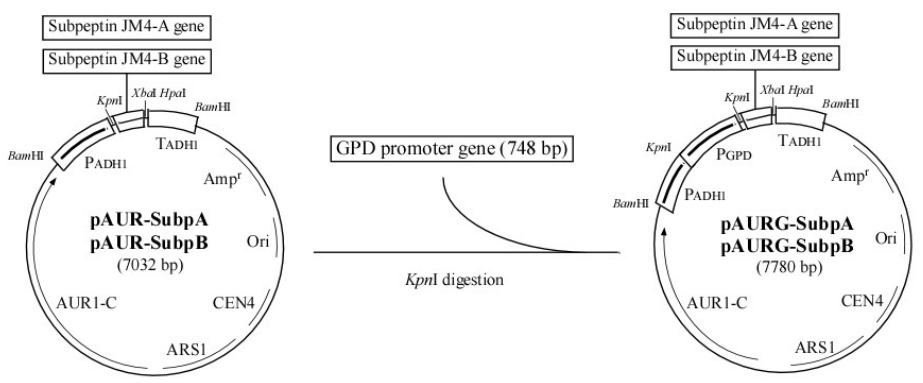

C
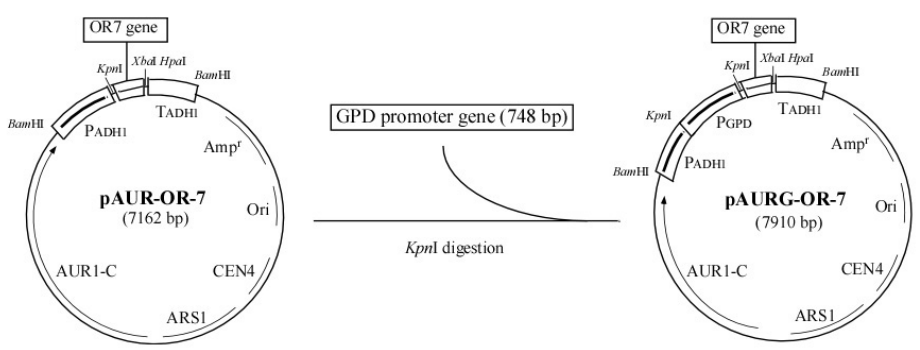

Fig. 2. Constructions of the yeast expression plasmids. The GPD promoter genes were inserted into a KpnI site of pAUR123, pAUR-SubpA, pAUR-SubpB and pAUR-OR-7 to yield pAURG (A), pAURG-SubpA (B), pAURG-SubpB (B) and pAURG-OR-7 (C), respectively. AUR1-C; S. cerevisiae aureobacidin A resistant gene, PADH1; S. cerevisiae ADH1 gene promoter, TADH1; $S$. cerevisiae $\mathrm{ADH} 1$ gene termination signal, ARS; S. cerevisiae replication origin, CEN; S. cerevisiae centromere, Ampr; E. coli ampicillin resistant gene, Ori; $E$. coli replication origin.
A

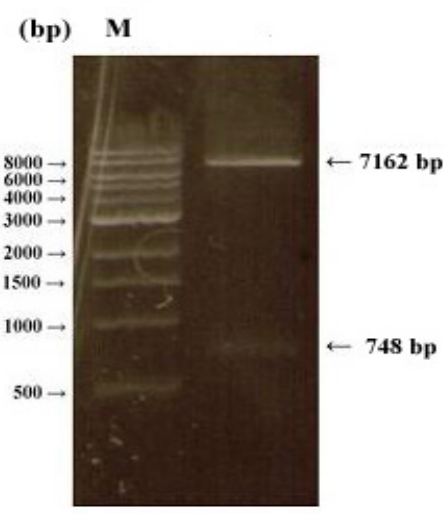

B

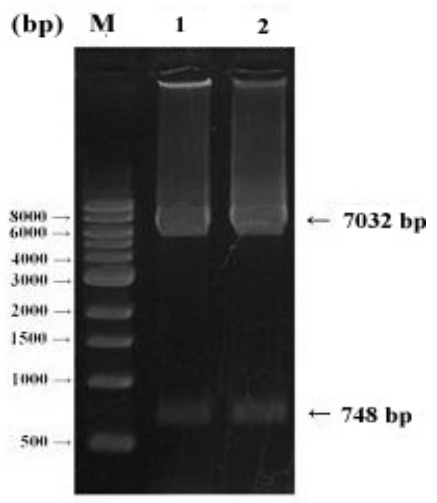

Fig. 3. Confirmation of the GPD promoter gene fragment from yeast cells transformed by pAURG-OR-7 (A) and pAURG-SubpA or pAURGSubpB (B). M; size marker, 1; pAURG-SubpA, 2; pAURG- SubpB.
들에 비해 본 연구를 통해 개발된 GPD 프로모터에 의해 박테 리오신 유전자를 발현시키는 형질전환 효모들에서 전반적으 로 세균에 대한 높은 생육억제능을 나타내는 것을 확인하였다 (Fig. 4, 5). 박테리오신 유전자를 가지지 않는 효모발현 vector 인 pAUR123과 pAURG를 도입시킨 형질전환 효모들의 경우 는 세균에 대한 생육억제를 나타내지 않았다(Fig. 4,5). GPD
프로모터에 의해 박테리오신 유전자의 발현이 유도되는 pAURG-OR-7 플라스미드 DNA가 도입된 형질전환 효모의 세균생육 억제환의 크기를 기존의 $\mathrm{ADH}$ 프로모터에 의해 박 테리오신 유전자의 발현이 유도되는 pAUR-OR-7 플라스미드 DNA가 도입된 항균활성 효모의 세균생육 억제환과 비교한 결과, 그람양성 고초균에 대한 생육 억제환은 $3.2 \mathrm{~mm}$ 정도 
A
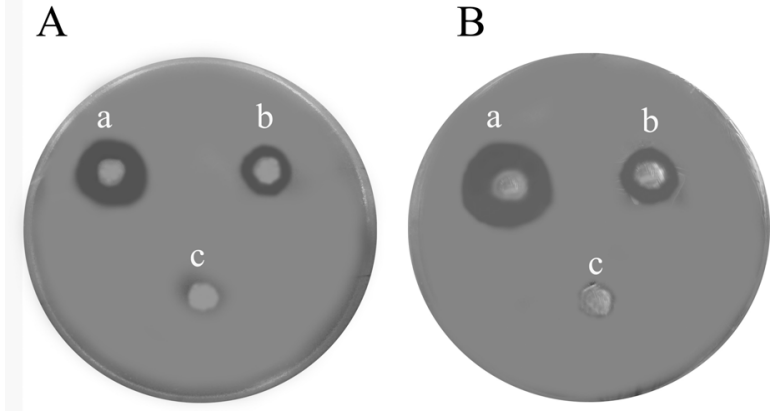

Fig. 4. Identification of the antibacterial activities of transformed yeast cells with the bacteriocin OR-7 gene. The antibacterial activities of transformed yeast cells against $B$. subtilis (A) and E. coli (B). a: S. cerevisiae harboring pAURG-OR-7, b: S. cerevisiae harboring pAUR-OR-7, c: S. cerevisiae harboring pAURG.
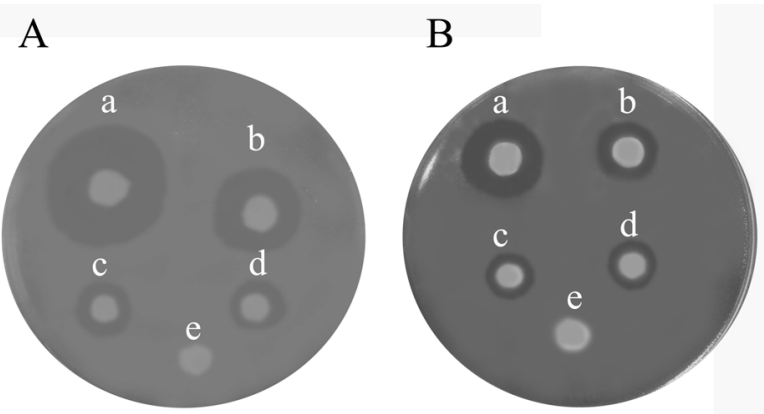

Fig. 5. Identification of the antibacterial activities of transformed yeast cells with the bacteriocin Subpeptin A or Subpeptin $B$ gene. The antibeacterial activities of transformed yeast cells against B. subtilis (A) and E. coli (B). a: S. cerevisiae harboring pAURG-SubpA, b: $S$. cerevisiae harboring pAURG-SubpB, c: S. cerevisiae harboring pAUR-SubpA, d: S. cerevisiae harboring pAUR-SubpB, e: S. cerevisiae harboring pAURG.

더 증가되었으며, 그람음성 대장균에 대한 생육 억제환은 4.1 $\mathrm{mm}$ 정도 더 증가된 것을 확인할 수 있었다(Fig. 4). 또한, 역시 GPD 프로모터에 의해 박테리오신 유전자의 발현이 유도되는 pAURG-SubpA 및 pAURG-SubpB 플라스미드 DNA가 도입 된 형질전환 효모들의 세균생육 억제환의 크기를 기존의 $\mathrm{ADH}$ 프로모터에 의해 박테리오신 유전자의 발현이 유도되는 pAUR-SubpA 및 pAUR-SubpB 플라스미드 DNA가 도입된 형질전환 효모들의 세균생육 억제환과 비교한 결과, 그람양성 고초균에 대한 생육 억제환은 각각 $7.3 \mathrm{~mm}$ 및 $2.8 \mathrm{~mm}$ 정도 더 증가하였으며, 그람음성 대장균에 대한 생육 억제환도 각 각 $4.4 \mathrm{~mm}$ 및 $1.9 \mathrm{~mm}$ 정도 더 증가한 것을 확인할 수 있었다 (Fig. 5).

본 연구에서 사용된 당대사 관련 단백질의 발현에 관여하는 GPD (glyceraldehyde-3-phosphate dehydrogenase) 프로모터
는 진핵생물에서 작용하는 강력한 프로모터로 알려져 있으며 $[8,16,17]$, 효모 및 곰팡이에서 이종의 단백질 발현량을 개선시 키는 연구에 사용되고 있다[16,17]. Lim 등[13]과 Seo 등[15]은 유도성 프로모터인 GALI 프로모터와 상시성 프로모터인 $\mathrm{GPD}$ 와 $\mathrm{ADHI}$ 프로모터를 사용하여 재조합 플라스미드 DNA 를 구축하여 사람 ferritin H, L-chain 및 포도당 산화 효소의 생산성을 증진시켰으며 또한, Chun 등[3]과 Kang 등[9]은 GALI 프로모터와 GPD 프로모터를 사용하여 효소의 생산 효 율을 증진시켰다. 본 연구에서도 박테리오신을 발현시키는 효 모 발현 플라스미드 DNA에 강력한 GPD 프로모터를 도입하 여 보다 강력한 항균활성을 나타내는 항균활성 효모의 제작이 가능하다는 사실을 확인할 수 있었다.

이 연구의 결과로 부패하기 쉬운 식품의 보존성을 향상시킬 수 있는 인공보존료를 대체할 수 있는 항균물질 혹은 가축에 있어 병원균의 생육을 저해하기 위한 항생제 대체물질로 사용 이 가능한 활성이 개선된 항균활성 효모의 개발에 성공하였다.

\section{References}

1. Antonio, G., H. Abriouel, R. L. Lopez, and N. B. Omar. 2007. Bacteriocin-based strategies for food biopreservation. Int. J. Food Microbiol. 120, 51-70.

2. Avis, T. J., R. Anguenot, B. Neveu, S. Bolduc, Y. Zhao, Y. Cheng, C. Labbe, and F. Belanger. 2008. Usefulness of heterologous promoters in the Pseudozyma flocculosa gene expression system. Biosci. Biotechnol. Biochem. 72, $456-462$.

3. Chun, B. W., D. H Kim, B. W. Chung, H. C. Lee, and M. S. Yang. 1996. Production of glucose oxidase using recombinant yeast. Kor. J. Biotechnol. Bieong. 31, 207-275.

4. Dixon, B. 2000. Antibiotics as growth promoters: risks and alternatives. ASM news. 66, 264-265.

5. Flynn, S., D. van Sinderen, G. M. Thornton, H. Holo, F. Nes, and J. K. Collins. 2002. Characterization of the genetic locus responsible for the production of ABP-118, a novel bacteriocin produced by the probiotic bacterium Lactobacillus salivarius subsp. salivarius UCC118. Mircrobiology 148, 973-984.

6. Friedman, C. R., J. Neiemann, H. C. Wegener, and R. V. Tauxe. 2000. Epidemiology of Campylobacter jejuni infections in the Unites States and other industrialized nations, pp. 121-138, In Nachamkin, I. and M. J. Blaser (eds.), Campylobacter, 2nd eds. American Society for Microbiology, Washing D.C.

7. Fuller, R. 1989. Probiotics in man and animal. Bacteriology 66, 265-378.

8. Gong, Z., Y. Su, L. Huang, J. Lin, K. Tang, and X. Zhou. 2009. Cloning and analysis of glyceraldehyde-3-phosphate dehydrogenase gene from Cordyceps militaris. Afr. J. Agric. Res. 4, 402-408.

9. Kang, H. K., H. J. Chun, and M. W. Lee. 2000. The optimization of recombinant protein production using $S$. cerevisiae mutant Y334 suitable for Gal promoter. Kor. J. 
Biotechnol. Bioeng. 2, 181-187.

10. Kim, H. Y., Y. J. Lee, K. H. Hong, Y. K. Kwon, J. Y. Lee, and S. H. Kim. 1999. Studies on the development of natural preservatives from natural products. Kor. J. Food Sci. Technol. 31, 1667-1678.

11. Lee, O. H., M. K. Jang, D. G. Lee, I. H. Kim, J. H. Lee, J. M. Ha, B. J. Ha, I. Y. Ahn, D. I. Cho, and S. H. Lee. 2008. Establishment of an antibacterial yeast that producing bacteriocin Subpeptin JM4-A or Subpeptin JM4-B. J. Life Sci. 18, 287-290.

12. Lee, O. H., M. K. Jang, D. G. Lee, J. H. Lee, J. M. Ha, B. J. Ha, I. Y. Ahn, D. I. Cho, and S. H. Lee. 2008. Construction of a bacteriocidal yeast producing bactericin OR-7. Kor. J. Microbiol. Biotechnol. 36, 101-105.

13. Lim, Y. Y., E. H. Park, J. H. Kim, S. M. Park, H. S. Jang, Y. J. Park, A. Y. Yang, M. S. Yang, and D. H. Kim. 2001. Enhanced and targeted expression of fungal phytase in Saccharomyces cerevisiae. Kor. J. Microbiol. Biotechnol. 11, 915-921.

14. Park, J. H., N. S. Han, J. Y. Yoo, D. J. Kwon, H. K. Shin, and Y. J. Koo. 1993. Screening of the foodstuffs influencing the growth of Bifidobacterium spp. and Clostridum perfringens. Kor. J. Food Sci. Technol. 25, 582-588.

15. Seo, H. Y., E. S. Jeon, Y. J. Chung, and S. K. Kim. 2002. Heterologous expression of human ferritin H-chain and L-chain genes in Saccharomyces cerevisiae. Kor. J. Biotechnol. Bioeng. 2, 162-168.

16. Varma, A. and K. J. Kwon-Chung. 1999. Characterization of the glyceraldehyde-3-phosphate gene and the use of its promoter for heterologous expression in Cryptococcus neoformans, a human pathogen. Gene 232, 155-163.

17. Wolff, A. M. and J. Arnau. 2002. Cloning of glyceraldehyde-3-phosphate dehydrogenase-encoding genes in Mucor circinelloides (Syn. racemosus) and use of the gpdI promoter for recombinant protein production. Fungal Genet. Biol. 35, 21-29.

18. Young, K. D., M. Koo, and C. R. Ryoo. 2002. Bacteriocin produced by Pediococcus sp. in Kimchi and its characteristics. Kor. J. Microbiol. Biotechnol. 12, 96-105.

\section{초록 : GPD 프로모터를 이용한 항균활성 효모의 활성증진}

장민경 · 유기환 · 김남영 · 이옥희 · 신재균 · 장혜지 · 이승우 · 이동근 · 이상현*

(신라대학교 제약공학과)

박테리오신의 항균활성 개선을 위해 선행연구에서 개발된 $\mathrm{ADH}$ 프로모터에 의해 박테리오신 유전자를 발현시 키는 효모발현 벡터에 GPD 프로모터 단편을 도입하여 강력한 프로모터를 가진 효모발현 재조합 플라스미드 $\mathrm{DNA}$ 를 제작하였다. $\mathrm{ADH}$ 프로모터에 의해 박테리오신 유전자를 발현시키는 기존의 형질전환 효모들에 비해 새롭게 개발된 GPD 프로모터에 의해 박테리오신 유전자를 발현시키는 형질전환 효모들이 그람양성 대표세균인 고초균(B.subtilis)과 그람음성 장내세균인 대장균(E. coli) 모두에서 보다 높은 생육억제환을 나타내는 것을 확인 하였다. 이 연구의 결과로 GPD 프로모터에 의해 발현이 유도되는 박테리오신 생산 효모들을 이용하여 부패하기 쉬운 식품들의 보존성을 향상시키기 위한 보존제 대체물질 또는 가축 사료에서 병원균의 생육을 저해하기 위한 항생제 대체물질의 산업적인 생산이 가능하게 될 것으로 기대된다. 